Foster, Thomas W. 1984. "Separation and survival in Amish society." Sociological Focus 17:1-15.

Foster, Thomas W. 1987. "The Taoists and the Amish: kindred expressions of ecoanarchism." The Ecologist 17: 9-14.

Hostetler, John A. 1993[1.980]. Amish Society. Baltimore: The Johns Hopkins University Press.

Hostetler, John A. 1989. Amish Roots: A Treasury of History, Wisdom and Lore. Baltimore: The Johns Hopkins University Press.

Joll, James. 1966. The Anarchists. New York: Grosset and Dunlap.

Kraybill, Donald B., J.A. Hostetler and D.G. Shaw. 1986. "Suicide patterns in a religious subculture: the Old Order Amish." International Journal of Moral and Social Studies 1: 249-262.

Kraybill, Donald B. 1989. The Riddle of Amish Culture. Baltimore: The Johns Hopkins University Press.

Kraybill, Donald B. and Steven M. Nolt. 1995. Amish Enterprise: From Plows to Profits. The Johns Hopkins University Press.

Olshan, Marc A. 1980 "The Old Order Amish as a model for development." Ph.D. Dissertation, Cornell University.

Parsons, William T. 1986. "The pemicious effects of Witness upon plain-worldly relations (in) Werner Enninger et. al. Internal and External Perspectives on Amish and Mennonite Life. Essen: Unipress.

Plancke, Fritz. 1986. "The Amish way: a Taoist approach" (in) Werner Enninger et. al. Internal and External Perspectives on Amish and Mennonite Life. Essen: Unipress.

Redekop, Calvin W. and John A. Hostetler. 1977. "The Plain People: an interpretation." The Mennonite Quarterly Review 51:266-277.

Schumacher, E.F. 1977. Small is Beautiful: Economics as if People Mattered. New York: Harper and Row.

\section{IDEOLOGY AS RESPONSE: CULTURAL AND POLITICAL PROCESS IN THE SANCTUARY MOVEMENT}

\author{
COLLEEN GREER \\ Bellevue University
}

MARS/Social Thought \& Research, 1997, Vol. 20, No. 1-2

\begin{abstract}
This paper examines the ideology of the Sanctuary Movement on behalf of Salvadoran and Guatemalan refugees displaced by domestic turmoil and war. This movement coalesced in the United States in the 1980s out of disparate efforts to assist particular refugees. Three interpretations of the role ideology are assessed: ideology as a resource for pursuing interests; ideology as a value system informing grievances; and ideology as sociallyconstructed frames realigned through discourse. It is found that core aspects of the ideology of the Sanctuary Movement emerged as individuals and church congregations came to terms with the needs and actions of those they belped and the U.S. government's opposition. Much of the ideology of the Sanctuary Movement was worked out by participants as they acted after the movement was underway. Analysis of $i d e o l o g y$ as a response is essential to relate the Sanctuary Movement to both the broader political culture and the political process with which it engaged.
\end{abstract}

\section{Introduction}

Recent work in the area of social movements and collective behavior has challenged the examination of social movements as formally structured organizations which function primarily on the basis of the existence or nonexistence of resources, and has moved the discussion toward a reexamination of the actor, the social context; and the sociopolitical culture within which social movement action is embedded. Central to these discussions is an effort to reexamine how actors link action and meaning to the broader culture. For example, how is it that encounters within an environment are framed, analyzed, and tied to themes of rights, freedom, individualism, protection, and economics? 
Ideology is a central component in the development and life of a social movement. Yet the complexity of the symbolic frames that compose it, and the manner of its emergence are often obscured by attempts to intertwine ideology and interests or by examining ideology as a package of preexisting norms and values that guide action (Melucci 1992, p. 131; Fine 1993, p. 21). Interpreting social movements as dynamic forms of collective action and social organization requires a closer examination of symbolic forms and the way in which meaning is produced. Analyzing ideology as a key component of collective action raises questions about the representations as well as the social contexts within which they are framed. This paper will examine the way ideology emerges and is changed; how it exists as political culture; and how it is framed as political process within specific social contexts.

The emergence and creation of ideology in social movements is tied to cultural frameworks as well as socioeconomic and political conditions (Moaddel 1992, p. 360; Gamson 1988, p. 220; McAdam, McCarthy and Zald 1988; Steinberg 1989; Fine 1993). Within these cultural frameworks ideological packages exist as cultural themes, and act as underlying constructs against which issues are developed and injustices are framed by contenders (Gamson 1988, p. 220; Tumer and Killian 1987 , p. 278). These packages come into play as movements attempt to mobilize and engage in collective action. Yet simply asserting that cultural themes exist does not provide an adequate analysis of the dimensions of ideological forms or the points at which actors use various forms to establish meaning. While cultural themes exist, the extent to which they provide meaning in a movement is related to the process through which discourse is established and used by participants within particular social networks.

Interpretations about the role of ideology in social movements show three tendencies that often overlap in application. These three tendencies include: 1) ideology as a resource used by groups to achieve interests; 2) ideology as a value system through which grievances and social relationships are assessed and tied to action; 3) ideology as a social construct in which frames are realigned through discourse (Turner and Killian 1987, pp. 236, 282-283; McAdam, McCarthy and Zald 1988, pp 727-728; Steinberg 1989, p.33; Melucci 1989; 1992). These interpretations may be traced to resource mobilization theories, collective behavior analyses, and new social movement discussions, and offer insight to framing processes. The following section will draw out distinctions between the perspectives and will focus on the development of ideology through discourse by social movement actors.

\section{Ideology--Roles}

The focus on ideology as a resource can be traced to Oberschall's interpretation of ideology as a resource to be used (not to be explained) in attempting to develop organizational forms and construct group goals (McCarthy and Zald 1973; Oberschall 1973, pp. 180-181, 194-5). This view takes social psychological processes and relationships as a given, deemphasizing variances in grievances, consciousness, cultural processes and action.

Other resource mobilization theorists pick up this view and connect ideology to resources and strategies Jenkins 1983, p. 528; McCarthy and Zald 1977). Ideology is not seen as a separate reinforcing dimension of social relations it is tied instead to selective or collective incentives and the realization of those incentives for the group (Olson 1965, pp. 132-33; Gamson 1990, pp. 68-71). McCarthy and Zald approach a discussion of ideology when they note that the distribution of preference structures is important. However, their focus then shifts to preexisting organizational forms and integrating those individuals who share preferences (McCarthy and Zald 1977, p. 1218). Ideology is created by movement leaders and appears useful in representing the movement organization to outsiders, but the integrating or social cohesion aspect is implicit, and although central to the process, it is not explicitly explored as an extension of everyday development of meaning (McAdam, McCarthy and Zald 1988, pp. 726-727).

Recent theorists, attempting to broaden the scope of resource mobilization theory, have moved beyond this framework viewing ideology as part of a broader conceptual theme and as a mediating component which assists in interpreting the relationship between group goals and individual interests (Gamson 1988, p. 220; Ferree and Miller 1985, pp. 41-2; Carden 1978, pp. 186-187; Mueller 1992, pp. 1-22). Carden suggests that collective incentives may be reclassified as ideological incentives and supplement other selective incentives as motivators for participation (1978, p. 185). Ideology provides mediation by showing levels of relationships among actors and activities, and by connecting possibilities for change to those relationships. Broad statements of ideology, like those associated with the feminist movement (e.g., "Traditional interpretations of women's roles are wrong."), provide room for personal action based in interpretations about morality and change (Carden 1978, p. 193).

In a similar revisionist vein, Ferree and Miller interpret ideology as a flexible structure of beliefs which defines social relationships, the social structure, and causes and consequences of action (1985, p. 41-42). Ideology is still tied to resources and works to support development of 
movements in the wider society (Ferree and Miller 1985, pp. 54-55). However, connections between social networks and cognitive processes still must be reinserted as an important dimension that is related to, but is not subsumed by, coercion and incentives.

Collective behavior theorists have emphasized ideology as an important component in assessing belief systems, grievances and social relationships. Smelser suggests the importance of ideology by analyzing it as one component which sheds light on the character of "generalized beliefs." He asserts that particular types of ideology will draw people into movements associated with normative change and revolution (Smelser 1962, p. 81). It is the way in which social strain, grievances, and dissatisfaction are made meaningful to possible participants (Smelser 1962 , p. 16) and helps to re-orient disoriented individuals in conditions of social strain (Moaddel 1992, p. 353). Concern about participation is an ongoing theme in Snow and others' social movement theories of action. Issues of participation and development of grievances are analyzed through interpretations, centered in frame alignment, which focus on individual and collective action in a movement as a function of both social psychological and structural/organizational factors (Snow, Rochford, Worden and Benford 1986, p. 464). Klandermans (1992, pp. $85-86)$, attempting to interpret the connection between social protest and multiorganizational fields, asserts that protest meanings are established through clashes of opposing schemes in individuals' "interpersonal life circles." Meanings are established that define some conditions as "grievances" and receiving collective goods as "success expectations" (Klandermans 1992, pp. 99-100). The complex interplay between movement organization, the opposition, and those outside the field of interest is central to the establishment of meaning (Klandermans 1992, pp. 85-86, 99-100).

In a similar manner Turner and Killian conceptualize ideology as a normative view of reality which incorporates a sense of injustice for the particular collective. Since Tumer and Killian see ideology and goals evolving together, they frequently refer to them as a movement's value orientations (Tumer and Killian 1987, pp. 262-283). They suggest that value orientations are used by a movement to provide guidance, foster solidarity, appeal for support, and represent the movement to outsiders (Turner and Killian 1987, pp. 278-279). In this interpretive framework ideology emerges through interactive processes in which a sense of injustice develops. In a sense through these processes individuals and groups "do ideology" (Fine 1993, p. 25). To "do ideology" implies more than a simple enactment of previously existing views; it is a formative process within which ambivalence appears as meanings and goals are expressed and internal conflicts are disguised. On another level the
Ideology as Response

emergence of ideology reveals the way in which conflict, and the position of particular movements, draws together social actors within a particular relational field (Melucci 1992, pp. 137-138).

\section{Ideology--The Emergence of Political Process}

These theoretical interpretations inform recent discussions of ideology which attempt to link macro and micro levels in order to explain the way in which injustice is framed and mobilization occurs. Analysis suggests that at the micro level social movement ideology is created through interaction among networks of individuals who begin to define actions as unjust (Gamson 1992; Steinberg 1989, p. 27). The framing of injustice occurs as circumstances are encountered which threaten existing values and accepted conditions (Tumer and Killian 1987, pp. 262-264).

The issues identified and the meanings associated with those issues are embedded within cultural definitions and conditions which are tied to institutional structures. In a social constructionist framework structures are not reified forms, but exist as social systems of interaction in which actors engage in the reconstitution and redefinition of the structures themselves (Lee 1990, p. 2). Through interactions within social networks, (i.e. friendship networks, relatives, work associates, other social movements), injustice frames develop which redefine the actions of authorities or dominant cultural themes and structures as problematic (Gamson 1992; Tumer and Killian 1987, pp. 265-266; Snow et al. 1986, p. 466). As collective definitions of injustice are formed, new roles are established that redefine actors as well as the social networks of which they are a part. $^{1}$

However, questions remain about the impetus to defining a condition as unjust. Recent analyses suggest that collective definitions of injustice are connected to awareness, action, and framing processes (Turner and Killian 1987, p. 267; Snow et al. 1986, p. 465). It is through action (including discourse) that ideology emerges. Activists "leam by doing" and their knowledge production reflects the accumulated experiences of the past; ideology is the outcome of a series of social encounters. Eyerman and Jamison refer to this as "cognitive praxis," knowledge creation as collective process (Eyerman and Jamison 1991, pp. 55-57). Ideology, in this view, becomes an indicator of change within a movement and between the movement and the surrounding

${ }^{1}$ Actors are redefined as victims, constituents, etc. In a similar way the networks that they are a part of must take in the change in role and redefine the interaction, providing an enlanged context. 
environment (Carithers 1982, p. 811). The Sanctuary Movement provides a specific case in point. This discussion suggests that interpreting the manner in which actors "do-ideology" requires a closer examination of the processes directly related to action and knowledge production in the life of a particular social movement. How does ideology emerge from collective activity? What type of social change occurs? The following discussion will address these issues by focusing on the behavior of actors, the emergence of ideology, forms of discourse, and the way in which ideological frames call forth opposing frames. A careful examination of the Sanctuary Movement will provide a clearer picture of the role of ideology in the life of a social movement.

\section{The Sanctuary Movement}

In January, 1981, war between the governing junta in $\mathrm{El}$ Salvador and leftist guerrilla forces turned about two-thirds of that country into a battleground. Military forces responded with counterinsurgency measures. As violence continued there, thousands of civilians were killed and over 100,000 refugees left the country and headed north, seeking political asylum. The concept of sanctuary was brought to the foreground as individuals in Mexico and the United States tried to deal with the flow of abused and dispossessed persons from Guatemala, as well as El Salvador, crossing their borders. Religious individuals perceiving governmental responses to the problem to be inadequate turned to concepts of sanctuary, based biblically in the stories and laws of Exodus and Numbers. They recognized that "sanctuary" has often referred not only to a sacred place set aside for the worship of God but also to a place of refuge and asylum where fugitives were protected. ${ }^{2}$

Providing sanctuary, a haven for the persecuted, became a frequent response to the human suffering of the refugees from Central America. Many of those who helped, especially those that lived along the southwestern border of the United States, stepped into the middle of controversy. By offering sanctuary churches entered the political arena, asserting that what appeared to be just by standards of the state was not just by biblical standards and frequently-used theological interpretations.

For Sanctuary Movement participants, and for the refugees from El Salvador and Guatemala, it appeared that justice had broken down. Through the Sanctuary Movement, Protestant and Catholic Churches as well as Jewish synagogues moved out of the realm of the ${ }^{2}$ The practice of sanctuary continued periodically from biblical times into the middle ages,
providing safe haven for people avoiding unjust persecution. purely sacred, declaring that the state was wrong, both at home and abroad. ${ }^{3}$ What is just? Who rules, God or Caesar? These questions faced participants in the Sanctuary Movement, and their answers became the ideological focus of the movement.

The ideology of the Sanctuary Movement developed out of political and theological interpretations involving action, rights, protection and support. Participants had been acquainted with the plight of the refugees through media reports and inter-church communications, yet no specific movement, collective action, or ideological orientation developed until individuals began to pick refugees up out of the desert, requested assistance from friends and church affiliates for their care, and sought governmental assistance in providing the refugees with asylum. Through interaction in social networks theological interpretations about the oppressed, government policies on refugees, and concems about rights merged into an ideology that continued to evolve over the life span of the movement (Greer 1990, pp. 1-4). Ideology was established and shared symbols developed through oppositional practices, with ideological frames serving as a justification for action, a critique of activity, and an assertion of future practice (Fantasia 1988, pp. 16-19). ${ }^{4}$

Providing sanctuary for refugees may be connected only in part to existing meanings, and must be seen in a more integrated context as a practice through which alternative meanings developed both for and against sanctuary. Past action in movements and awareness of movement activity created a knowledge of organization and state intervention as well as a tendency toward interpretation based on religious, moral, and spiritual values and beliefs. Additional themes appeared as activists working with informal knowledge (Eyerman and Jamison 1991, p. 44) encountered private social service agencies with an

${ }^{3}$ Ironically, biblical interpretation and theology also framed the crisis in El Salvador and Guatemala. New forms of theological interpretation in the Catholic Church offered hope and created a crisis for citizens in Central America. This "Liberation theology" moved church and state into conflict. Liberation theology was officially proclaimed by Catholic bishops at a conference in 1968 in Medellin, Columbia and as practiced by priests in El Salvador and Guatemala became a rallying poin for the oppressed. The bishops noted inustice in Lain Amerca and called for innovat remove barriers and grant rights to individuals in the region (Crittenden 1988, p.15). Parish priest drawing on this declaration continued with the development of study groups called "base communities," in which people were told to read the Bible and apply it to what was happening in their daily lives. A more radicalized version sprang from the Santiago Conference in 1972 Developing Liberation theology through a class analysis of poverty led to an integration of faith and politics that sought liberating social changes (Brown 1978, p.59).

${ }^{4}$ Oppositional practices included picking up refugees from the desert, accompanying aliens to Immigration and Naturalization Service offices, reading and constructing pamphlets about U.S. policy and freedom. 
orientation based on the nonviability of the concept "border," and interpretations in which action was seen as a response to the political and economic realities associated with the enforcement of a constructed boundary and ascribed identities for Hispanics. Yet the social encounters (e.g., filing asylum requests with the U. S. Immigration and Naturalization Service (INS), organizing pick-up sites, housing refugees, conducting prayer vigils, organizing discussions among congregational members, connections with local social service agencies), provided a context in which these tendencies were highlighted and reassessed (Davidson 1988, pp. 26-27; Crittenden 1988, p.27).

Through dialogues about the results of "following the rules" to "acquire political asylum and protecting refugees by helping them to go "undetected" (a suggestion from the Manzo Area Council, a private social service agency), multiple responses emerged. Activists functioning within a framework that encompassed both rights and moral reasoning moved from seeing the INS as focused on efficiency to a perspective based in active resistance:

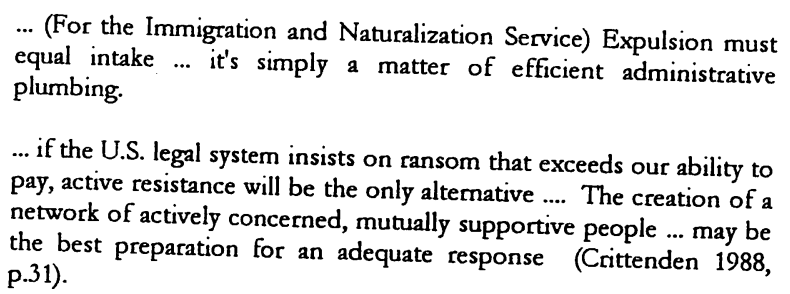

As actors engaged in frame alignment processes initial conceptualizations of meanings were modified to develop partnerships between local churches as well as between movement adherents in Tucson, California, and Chicago (Greer 1990, pp. 19-20). At the same time internal opposition to sanctuary and disagreement between organizational sectors of the movement created an environment in which ideological forms were called into question. In the process of assessing the existing forms, adherents began to encompass a new conceptual framework, "betrayal," alongside a conceptual realignment by adherents of internal and external opposition.

Actions by adherents in the Sanctuary Movement suggest that ideology does not necessarily precede a movement, nor does it simply act as a resource. Ideology is frequently created through discursive practices, suggesting ideology as response. Ideology as response is embedded in action and contains two important aspects for interpreting ideology as a social construction. The first aspect involves discourse, symbolic systems, and discursive change. The second refers to political forms that develop. The first provides insight into the creation and change of ideology. The second relates this concept to political process.

Discourse provides the context within which actors frame injustice ideologies in an attempt to develop meaning for their worlds (Steinberg 1989, p. 23). Discourse exists as action and operates at many levels in the social structure both as text and speech (Steinberg 1989, p. 31). In order to interpret the way in which discourse carries injustice frames a careful examination of language forms, the status of participants, and sociocultural elements within the setting is necessary (Corsaro 1985, p. 179; Cicourel 1980).

Language forms in the Sanctuary Movement included utterances conceptualized as "speech acts," as well as texts in the form of declarations, liturgy, story, and letters. Speech acts encompass everyday forms of talk as well as formalized moments during which written texts and verbal pronouncements are merged and the passive elements that are part of written text take on an active form (Kress 1985, pp. 34-35). In the Sanctuary Movement participants engaged in codified speech events that allowed the hidden to be made known.

We have a special tonight.

Can you house someone tonight? (Coutin 1993, p.29)

As participants were confronted with the term "we," they were exposed as activists. The discourse maintained secrecy as it disclosed the emerging agenda of the movement by asking participants to "house" refugees. At the same time worship services, prayer vigils, and meetings provided contexts within which participants engaged in both formal and informal dialogical patterns. Everyday talk of fear, crisis, and ethical responsibility became formalized in written liturgies that were repeated by entire congregations (Davidson 1988, pp.72-73; Crittenden 1988). At the same time speech acts (i.e., sermons, declarations of sanctuary, press releases) by adherents, participants and non-participants within the context of government agencies, congregations, and the press exhibited attempts by social movement leaders to bring order to forms of everyday talk and to momentarily solidify ideology.

The above discussion suggests that context is central to the interpretation of a speech act, and the way in which the injustice ideology is carried forth. Yet questions remain about how utterances are used and by whom? Who is listening and what is the response? Definitions of status within social movements include the degree to which individuals are inside, on the periphery, or outside the movement (i.e., adherents, participants, beneficiaries). However, at another level status reflects the position of participants within particular speech events (Bilmes 1986, pp. 
132-133), suggesting distinctions between participant speakers and hearing participants. As participants change positions during particular social encounters, meaning is established through participant reaction.

Salvadoran and Guatemalan refugees who crossed the border provided accounts of their lives in Central America to activists and Immigration and Naturalization Service agents. The utterances elicited multiple responses from hearing participants. Refugees as hearing participants rediscovered connection to Central America at the same time that they reencountered images of friends, relatives, displacement, and death. Sanctuary Movement activists as hearing participants interpreted refugee accounts as stories that provided connection to abstracted images of oppression and crisis eliciting responses of assistance, fear, and "resistance as political struggle"/"resistance of responsibility."

Over the course of the movement, accounts by refugees became stories repeated within public settings by disguised refugees. As hearing participants encountered these speech events, an interpretation of fabrication was expressed through response. Fabrication as a response elicits an interpretation based in an understanding of difference between what is presented and what is intended; it is not singular in dimension but is multi-layered suggesting additional interpretations by participants based on this frame (Goffman 1974, pp. 84-87). As differences between accounts and stories were identified, some participants interpreted refugees acceptance of assistance but reluctance to speak as additional indications of fabrication and felt that sanctuary workers had "been had."

The sense of having "been had" (Goffman 1974, p. 85) is also a response elicited from Immigration and Naturalization Service officials as they encounter the stories of Salvadorans and Guatemalans. Night runs by movement participants to pick up migrants, multiple requests from asylum containing well clarified identical stories, public events with refugees speaking in disguise, and declarations of sanctuary provided images of exploitation and evoked suppressive forms of legal action by Immigration and Naturalization Service agents against refugees as well as movement participants.

Differences highlighted by responses of fabrication are evident among participants within the movement. While some participants elicited responses of having "been had" and created additional distance by focusing energy on political change, (i.e., requesting refugees who would cooperate), others attempted to bridge the difference by
immersion.

The most important thing [about sanctuary work] is just learning to experience ... that brought that home the most was our experience in Aguacayo [when we] went down to accompany a group of displaced people ....

By reasserting the honesty of refugees' stories and the need for identification, movement participants attempted to overcome the sense of "being had." However, the reassertion of refugee values (intentions) and experience as true only partially offset the response of fabrication since the use of stories within particular contexts provides for the continuation of alternative themes. In addition, by highlighting "their" values and "their" experiences as truth, movement participants reassert categorical distinctions in identity and culture that emerged from initial responses of fabrication. The connection of truth with particular categories raises questions about the potential for solidarity within the movement.

Events associated with the Sanctuary Movement suggest that while meaning develops through discourse, it does not exist in consciousness but in the field of experience (Mead 1934, pp. 76-78). Therefore, ideology as response implies a dynamic process whereby meanings are developed through discourse (McPhail 1991, p. 197) and factored back into future exchanges as new information modifying the response (verbal and behavioral). Discourse provides opportunities for participants to bring competing definitions and unintended consequences into alignment and highlights aspects of ambivalence which are frequently moved to the periphery (Snow et al. 1986, pp. 465-466; Melucci 1992, pp. 137-138). It allows actors to connect lived experience to meanings about aspects of the world that they have not experienced directly (Steinberg 1989, p. 33). Action (i.e., attendance at a rally, picking up a hitchhiker from El Salvador, talking to a refugee) emphasized ambivalence and created situations in which meanings are adjusted and action (i.e. discourse) continues as rejection, acceptance, or reform (Melucci 1989). Ideology therefore comes before and after action, but also through it as actors create concepts. ${ }^{5}$

Discourse provides both a role for the actor (i.e. social movement participant) as well as the capacity for collective action. Contained within this process is both the potential for control and for criticism. This is evident in the Sanctuary Movement as participants attempt to solidify themes around concepts of sanctuary. The potential for control, when overlapped with power, provides an opportunity for actors to formalize the terms through which meanings are assigned and

5This relates to Taylor and Whittier's (1992 p. 114) conception of consciousness as interpretive frameworks that emerge from a group's struggle to define and realize members' common interests. 
action takes place. However, as is evident by participant "betrayal" of the declaration of sanctuary to the press, the potential for criticism and realignment also exists.

Through discourse, existing ideologies and conditions in the broader culture are factored into ideological boundaries. For example, individual rights and theological interpretations of salvation and sanctuary were used by Sanctuary Movement participants. Concepts of the "kingdom" framed action and attracted Quaker Friends of Corbett into participation. The same themes existed in future correspondence with other denominations and networks as the address changed from "Friends" to "friends," providing opportunities for realignment but also opening the door to decisions about repertoires and their use in movement discourse and ideological change (Crittenden 1988, p. 44 Steinberg 1989, pp. 38-42).

Snow, Rochford, Warden, and Benford (1986, p. 467) attempt to interpret this process by analytically defining it as frame alignment Frame alignment contains four processes: frame amplification, frame bridging, frame extension, and frame transformation. They assert that during mobilization campaigns social movement organizations attempt to connect the meanings of the individuals to the organization through these processes (Snow et al. 1986, pp. 467-469). However, in applying this analysis of framing to participation the dynamic character of discourse and ideology as response is. not captured. Although their model posits interaction, it focuses on connecting actors to the organization in a manner consistent with interpretations of structure and loses elements of agency. Steinberg (1989, p. 27) notes that, "Constituents seem to be passive elements in the process beyond their acceptance or rejection of the frame." It loses the dynamic character of ideology and the multiple forms of response that are possible.

However, Snow, Rochford, Warden, and Benford's conception does capture aspects of discourse previously missed and is particularly relevant in instances where leaders attempt to create and formalize ideology and present it as a package to their constituents. It sets boundaries around those moments in time, such as the declaration sanctuary, when movement leaders attempt to create momentum within the movement and a united front to potential participants and opponents. A critique of Steinberg may in fact be in order. Even when ideology is handed to individuals to accept or reject the possible participants "respond" creating meanings that will affect the existing discourse (Greer 1990).
Ideology as Response

Therefore, ideology as response occurs prior to the establishment of a social movement organization as well as through organizational processes. Interpreting ideology as response highlights the dynamic character of meaning construction and the way in which it assists in creating opportunities for shifts in structures and decision making. ${ }^{6}$

Possibilities for stretching ideological boundaries or changing them through discourse may be seen in the shifts that occurred as identity issues emerged among some participants within the Sanctuary Movement. While the initial focus of the movement on rights, protection, ethics and Immigration and Naturalization Service policy was accepted by many participants, it was also rejected and ignored which

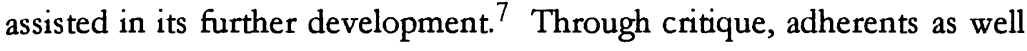
as other within the social context began to stretch the boundaries of meaning associated with the movement and incorporated an alternative discourse of personal transformation (Coutin 1993, pp. 56-60). Crossing the border went beyond the anti-institutional acts of liberal activists and participants interested in political change that would eliminate the conflict in definition between political and economic refugees or end the war in El Salvador.

Focusing on discourse and ideology as response mediates micro and macro distinctions and connects objective interests to subjective reality (Ferree and Miller 1985, p. 41; Steinberg 1989, pp. 30-35). ${ }^{8}$ Ideology as response plays a significant part in the definition of politics and the way in which actors engage in political process. Recognizing that it is through discourse that ideological frames are discemed and developed does not in and of itself explain collective action. However it does allow us to assess processes within which the framing of injustice and commitment to participation take place even though the impetus to particular acts (i.e., establishing a church as a sanctuary) is not completely explained. ${ }^{9}$

${ }^{6}$ This reflects elements of Snow and Benford's discussion of master frames (1992).

7Snow and Benford (1992) note that master frames are either restricted or elaborated. The former tend to be closed while the other is organized in terms of a wide range of ideas. The "rights" frame appears to be closer to an elaborated frame.

${ }^{8}$ Language is not the only form of discourse. Other forms include nonverbal gestures, rituals, etc.

'Snow and Benford (1992) refer to this as tactical innovation and connect it to the emergence of new master frames (1992 p. 146). This also relates to other interpretative frames within the society, particularly those that focus on the individual. As efforts were made to break with forms of 
The creation and change of ideology in social movements is directly tied to the political culture within which movements develop. Ideological responses are framed by and frame action at the cultural and social movement level, implying particular forms of activity and political process. The Sanctuary Movement developed during a time period and within a culture that had a history of protest, yet frames for action in the early 1980's were focused on containment, individualism, and privatization of issues, with an emphasis on returning to traditional values. It was within this environment that the Sanctuary Movement took form and devised initial strategies of one-to-one assistance which were consistent with the volunteerism emphasis and core values espoused in a broader culture.

\section{Political Culture}

The distinctions in ideology outlined above point toward the use of cultural concepts in the formation of political processes. Ideologies of social movements, like the Sanctuary Movement, develop in relation to a political culture which contains specific conceptual frames. These conceptual frames exist and are dispersed through institutions in society (e.g., economic, religious) as well as through the media. Societal institutions support these frames (e.g., technological progress, democracy) through particular policies and actions (Gamson 1988, pp. 220-221; Musolf 1992, pp. 173-175; Tarrow 1992).

However, each ideological frame implies an opposite frame, and when it is used by authorities or called into view by events (e.g. Chemobyl) it creates ambivalence about the frame itself (Gamson 1988, pp. 220-225; Klandermans 1992, pp. 79-80). To call one ideology into existence is to call up opposition, as well as subsets of issues which may or may not feed into a collective struggle. For example, concepts of individualism call up not only the opposite community, but also subsets of individualism which have been labeled by Bellah as utilitarian, expressive, biblical and republican (Bellah 1985, pp. 333-336). These subsets contain seeds of dissent as well as connection to other ideological themes (e.g., Liberation theology) that may already exist in opposition. Dominant cultural frames provide both constraint and opportunity for challengers.

Dominant themes of individualism that emphasized containment and interpreted Salvadorans and Guatemalans as economic

utilitarian individualism, individuals moved toward expressive forms that focus on the self and therapy (Bellah 1985, pp. 333-336). refugees in pursuit of financial self-interest, were picked up and challenged by participants in the Sanctuary Movement who emphasized concepts of self-interest in terms of well-being, containment, and protection. For example, social service workers who participated in the movement from the Manzo Area Council emphasized the self-interest involved in protecting U.S. economic interests by having a porous border and assisting refugees to obtain freedom (Crittenden 1988). While INS agents acted on the basis of freedom from restraint and constructed policies of containment, Sanctuary participants focused on subsets of individualism that emphasized freedom through community, a substantive freedom that is ethical in form (Davidson 1988; Bellah 1985, pp. 29-31).

The opposing cultural frame, community, and the sub-themes of individualism focusing on ethical freedom were often merged by participants with Liberation-theology interpretations of base communities. Although the merger established themes for opposition and connection to other social networks, they also provided an additional threat to the political apparatus of the Immigration and Naturalization Service who perceived Liberation theology as a threat to the success of American foreign policy in Central America.

Challenging groups and their discourse exist as part of a social movement sector which functions as an opposition conscience to conceptual themes supported by authorities (Turner and Killian 1987, p.267; McAdam, McCarthy and Zald 1988, p. 701; Gamson 1988, pp. 220-221). Although social movements assert distinct ideological frames, the formation process leaves behind elements of general conceptual frames as well as frames from other movements within the sector. Ideological responses that encounter environmental restraints or changes in the cultural climate are channeled into dominant conceptual forms, become part of other challenging groups within the social movement sector, or are maintained by particular subgroups of the movement who adhere to a change in consciousness (Snow and Benford 1992, pp. 149150). Immigration and Naturalization Service challenges to Sanctuary participants moved ideology of the movement toward an emphasis based on political agitation for changes in policy (Crittenden 1988).

\section{Political Process}

Political process as it is used in social movement literature involves the concept of opportunity structure and implies a situation in which the state becomes vulnerable to collective action (Tarrow 1989, p. 32; McAdam, McCarthy and Zald 1988, p. 701; Tilly 1978). Opportunity structures provide groups with openings that assist in protest. Ideology 
as response plays a significant role in political process as it functions to shape the way in which specific contenders approach the system. The processes associated with ideological formation in the Sanctuary Movement suggest that actions created in a social movement context are part of a political framework in which actors not only seek power but also call for structural change, personal transformation and withdrawal (Ferree and Miller 1985, p. 59)

Ideology frames and is framed by people engaging in collective action and plays a significant role in social movements and in the larger social context. As a mediator between opportunities and action it has the potential to affect mobilization as well as dominant cultural themes.

\section{REFERENCES}

Bellah, Robert, Richard Madsen, William M Sullivan, Ann Swidler Steven M. Tipton. 1985. Habits of the Heart: Individualism and Commitment in American Life. New York: Harper and Row.

Benford, Robert D. 1992. "Dramaturgy and Social Movements: The Social Construction and Communication of Power." Sociological Inquiry 62:36-55

Bilmes, Jack. 1986. Discourse and Behavior. New York: Plenum Press.

Brown, Robert McAfee. 1978. Theology in a New Key. Philadelphia: Westminster Press.

Carden, Maren Lockwood. 1978. "The Proliferation of a Social Movement. Ideology and Individual Incentives in the Contemporary Feminist Movement." Research in Social Movements, Conflict, and Change 1:179-196.

Carithers, Martha W. 1982. A Social Movement Career. National SDS. Ph. D. Dissertation, Department of Sociology, University of Kansas, 1982

Cicourel, Aaron. 1980. "Three Models of Discourse Analysis: The Role of Social Structure." Discourse Processes 3:101-132.

Corsaro, William A. 1993. "Sociological Approaches to Discourse Analysis." In Handbook of Discourse Analysis, Volume 1, Disciplines of Discourse, edited by Teun A. Van Dijk. London: Academic Press.
Coutin, Susan Bibler. 1993. The Cultures of Protest: Religious Activism and the U.S. Sanctuary Movement. Boulder. Westview Press.

Crittenden, Ann. 1988. Sanctuary: A Story of American Conscience and the Law in Collision. New York: Weidenfeld and Nicolson.

Davidson, Miriam. 1988. Convictions of the Heart. Tucson: University of Arizona Press.

Eyerman, Ron and Andrew Jamison. 1991. Social Movements: $A$ Cognitive Approach. Cambridge, U.K: Polity Press.

Fantasia, Rick. 1988. Cultures of Solidarity. Berkeley, CA: University of California Press.

Ferree, Myra. 1987. "Equity and Autonomy: Feminist Politics in the U. S. and West Germany." In The Women's Movements of the U. S. and Western Europe, edited by Fainsod Katzensteing and Carol Mueller. Philadelphia: Temple University Press.

Ferree, Myra Marx and Frederick D. Miller. 1985. "Mobilization and Meaning. Toward an Integration of Social Psychological and Resource Perspectives on Social Movements." Sociological Inquiry 55:38-61.

Fine, Gary Alan and Kent Sandstrom. 1993. "Ideology in Action: A Pragmatic Approach to a Contested Concept." Sociological Theory 11(1):21-38

Gamson, William A. 1991. "Commitment and Agency in Social Movements." Sociological Forum 6(1):27-50.

1988. "Political Discourse and Collective Action." International Social Movement Researcb 1:219-44.

1992. "The Social Construction of Protest and Multiorganizational Fields." in Frontiers in Social Movement Theory, edited by Aldon D. Morris and Carol McClurg Mueller. New Haven: Yale University Press.

1990. The Strategy of Social Protest. Second edition. Belmont: Wadsworth Publishing Company.

Genevie, Louis E., ed. 1978. Collective Behavior and Social Movements. Itasca: Peacock Publishers, Inc. 
Goffman, Erving. 1974. Frame Analysis: An Essay on the Oryanization of Experience. Boston: Northeastern University Press.

Greer, Colleen. 1990. "The Sanctuary Movement." Unpublished paper presented to the Social Movement Seminar, University of Kansas, Spring, 1990.

Jenkins, J. Craig. 1983. "Resource Mobilization Theory and the Study of Social Movements." Annual Review of Sociology 9:527-553.

Killian, Lewis M. 1980. "Theory of Collective Behavior: The Mainstream Revisited." in Sociological Theory and Research, edited by Hubert M. Blalock, Jr. New York: The Free Press.

1984. "Organization, Rationality, and Spontaneity in the Civil Rights Movement." American Sociological Review 49:770-783.

Klandermans, Bert. 1984. "Mobilization and Participation: Social Psychological Expansions of Resource Mobilization Theory." American Sociological Revien 49:583-600.

1992. "The Social Construction of Protest and Multiorganizational Fields." in Frontiers in Social Movement Theory, edited by Aldon D. Morris and Carol McClurg Mueller. New Haven: Yale University Press.

Kress, Nancy. 1985. Trinity and other Stories. New York: Blue Jay Press.

Lang, Kurt and Gladys Lang. 1961. Collective Dynamics. New York: Crowell.

Lee, Raymond. 1990. "The Micro-Macro Problem in Collective Behavio Reconciling Agency and Structure." Journal for the Theory of Social Behavior 20(3):213-233

McAdam, Doug, John McCarthy and Mayer N. Zald. 1988. "Social Movements." In Handbook of Sociology, edited by Neil Smelser. Newbury Park: Sage.

McCarthy, John D. and Mayer N. Zald. 1973. The Trend of Social Movements in America: Professionalization and Resource Mobilization. Morristown, N.J.: General Learning Press.
Ideology as Response

McCarthy, John D. and Mayer N. Zald. 1977. "Resource Mobilization and Social Movements: A Partial Theory." American Joumal of Sociology 82:1212-1241.

McPhail, Clark. 1991. The Myth of the Madding Crowd. New York: Aldine DeGryter.

Mead, George Herbert. 1934. Mind, Self, and Society. Chicago University of Chicago Press.

Melucci, Alberto. 1992. "Challenging Codes: Framing and Ambivalence in the Ideology of Social Movements." Thesis Eleven 31:131142 .

1989. Nomads of the Present: Social Movement and Individual Needs in Contemporary Society London: Hutchinson Radius.

Moaddel, Mansoor. 1992. "Ideology as Episodic Discourse." American Sociological Review 57:353-379.

Morris, Aldon D. and Carol McClurg Mueller, eds. 1992. Frontiers in Social Movement Theory. New Haven: Yale University Press.

Mueller, Carol McClurg. 1992. "Building Social Movement Theory." In Frontiers in Social Movement Theory, edited by Aldon D. Morris and Carol McClurg Mueller. New Haven: Yale University Press.

Musolf, Gil Richard. 1992. "Structure, Institutions, Power and Ideology: New Directions Within Symbolic Interaction." The Sociological Quarterly 33(2):171-190.

Oberschall, Anthony. 1973. Social Conflict and Social Movements. Englewood Cliffs, NJ: Prentice-Hall, Inc.

Olson, Mancur. 1965. The Logic of Collective Action. Cambridge: Harvard University Press.

Smelser, Neil J. 1962. The Theory of Collective Behavior. New York: The Free Press.

Snow, David A. and Robert D. Benford. 1988. "Ideology, Frame Resonance, and Participant Mobilization." International Social Movement Research 1:197-217. 
1992 "Master Frames and Cycles of Protest." Pp 133-156 in Frontiers in Social Movement Theory, edited by Aldon D. Morris and Carol McClurg Mueller. New Haven: Yale University Press.

Snow, David A., E. Burke Rochford, Jr., Steven K. Worden, and Robert D. Benford. 1986. "Frame Alignment Processes, Micromobilization, and Movement Participation." American Sociological Review 51:464-481.

Snow, David A., Louis A. Zurcher, and Sheldon Ekland-Olson. 1980 "Social Networks and Social Movements: A Microstructural Approach to Differential Recruitment." American Sociological Review 45:787-801

Steinberg, Marc W. 1989. “Talkin' Class: Discourse, Ideology, and Their Intersection." Paper presented at conference on "Bringing Class Back In: Contemporary and Historical Approaches," University of Kansas, April 4, 1989.

Tarrow, Sidney. 1989. Struggle, Politics, and Reform: Collective Action, Social Movements, and Cycles of Protest. Western Societies Occasional Paper No. 21. Center for International Studies, Comell University.

1992. "Mentalities, Political Cultures and Collective Action Frames." In Frontiers in Social Movement Theory, edited by Aldon D. Morris and Carol McClurg Mueller. New Haven: Yale University Press.

Taylor, Verta and Nancy E. Whittier. 1992. "Collective Identity in Social Movement Communities: Lesbian Feminist Mobilization." In Frontiers in Social Movement Theory, edited by Aldon C. Morris and Carol McClurg Mueller. New Haven: Yale Univeristy Press.

Tilly, Charles. 1978. From Mobilization to Revolution. New York, N.Y.: Random House.

Turner, Ralph H. and Lewis M. Killian. 1987. Collective Behavior. 3rd edition. Englewood Cliffs, N.J.: Prentice Hall.

\section{CITIZEN-STATE INTERACTION AND TECHNICAL CONTROVERSY: THE U.S. ARMY CHEMICAL STOCKPILE DISPOSAL PROGRAM*}

\author{
ROBERT FUTRELL \\ University of Kansas
}

MARS/Social Thought \& Research, 1997, Vol. 20, No. 1-2

This paper explores the development and transformation of a local collective campaign opposing the U.S. Army's Chemical Weapons Stockpile Disposal Program into a social movement with national and international dimensions. I examine the ways in which the actions of both citizens and the Army bave been shaped by officials, policies and organizations at multiple levels of the state. Contrary to the emphasis on extra-institutional actions noted in many studies of movements and collective action, I show that the social, political and scientific context of technical controversies with the state may place constraints upon and opportunities for action to be directed and sustained through institutional channels. Specifically, I explain the effects of political opportunities, "target vulnerabilities" (Walsh 1986) and specialized resources on the development and transformation of claims-making, forms of action, organizational structure and the expressed aims of the groups involved. I end with suggestions for practical distinctions and refinements in the concepts used in the analysis.

Technical controversies are inherently political (Mazur 1981; Levine 1982; Nelkin 1984; Powell 1984; Jasper 1988; Clarke 1990; Portney 1991; Benford, Moore and Williams 1993; Walsh, Warland and Smith 1993). Since 1970, government regulations over issues of technology and the environment have greatly increased at federal, state and local levels. Citizen protection against environmental hazards and the implementation of controversial technologies has, consequently, depended primarily on government controls (Kraft and Vig 1990). Challengers in technical controversies must often become enmeshed in

* Dr. Jack Weller's sharp insights have been especially helpful for the development of this work. I am also greatly indebted to the anonymous interviewees, without whom this research would have been rather stale and uniformed. This research was supported by a Grant-in-Aid of Research from Sigma Xi, The Scientific Researcb Society. 